\title{
THE UNIFORM COMMERCIAL CODE: A REPLY TO PROFESSOR BEUTEL
}

\author{
GRANT GILMORE $\dagger$
}

As Beutel tells the old tale, there was once upon a time a National Conference of Commissioners on Uniform State Laws which fathered seven Uniform Commercial Acts, one more beautiful than the other. There is also the story about the young girl who was as good as she was beautiful, from whose mouth diamonds fell at every word. Her name was Commercial Law. This lovely maiden had an ugly stepsister, Commercial Code, whose mother was a wicked witch known professionally as the American Law Institute. From the stepsister's mouth there came forth only loathsome toads and reptiles.

Now the seven Uniform Acts are not that good, nor is the Code that bacl.

I do not propose in these pages to undertake an affirmative defense of the Code. I shall restrict myself to commenting on the major points which Beutel has raised in his article. Point by point rebuttal is necessarily dull. I can promise my reader nothing but tedium: there is no reason for him to bear with it unless he is concerned with the validity of Beutel's reasons for argaing that the Code should not be adopted.

Beutel knows the Code well. He has been a regular attendant at the meetings of Conference and Institute and has taken an active part in discussions. His conclusions are based on long study and expert knowledge. In his paper he has presumably made the strongest possible case for rejection of the Code; he has put forward what he considers to be the most serious objections, the basic errors and fundamental flaws. Although there may be a great many left-overs, we are justified in assuming that this is the main dish; what Beutel did not choose to serve up here would be a pot-pourri of detail. If there is not a great deal to Beutel's major points, we may conclude that there is at least nothing seriously wrong with the Code: nothing as bad as the dream sequence of being out in public with no clothes on.

I shall not deal with each and every Beutelism. ${ }^{1}$ I shall attempt only to meet him fairly on the principal issues : boring the reader is one thing ; killing him outright is another.

†Professor of Law, Yale Law School. The author was a member of the drafting staff for the Uniform Commercial Code from 1948 to 1951. References to sections of the Codo are to the final (Fall, 1951) version unless otherwise indicated.

1. I do not mean to give the impression that, if time and space permitted, I could with ease dispose of everything Beutel has to say. Indeed on one major point and on several minor ones $I$ am in agreement with Beutel's criticisms although not with his conclusions. For the major point, see discussion of Article 4, Bank Collections, infra, p. 374. As an example of a minor point, see Beutel's discussion of the treatment 
No one-certainly not I-pretends that the Code is perfect.Anyone who does should have his head examined. Anyone who thinks that any team of legal and/or economic supermen could draft a perfect Code should have his head examined. I am not talking here of disputed or doubtful decisions on matters of policy, but of plain mistakes. The Code has its share. So does and so will every other statute ever drafted. It is basic to an understanding of the legislative process that, in the interplay between court and legislature, one of the important judicial functions is to clean up the messes which the draftsmen inevitably leave behind them.

Beutel apparently feels that a better Code could have been produced if twice as much time had been taken and if the drafting had been entrusted to a corps of full-time specialists instead of to a group of professors advised mostly by other groups of practicing lawyers. Beutel also suggests that the Code should have been based on economic analysis, research and investigation into the facts of commercial practice.

We overrate the results that can be achieved by hiring a team of specialists and having a survey made. The bigger the problem to be investigated, the longer the survey takes, the more it costs and the more doubtful the results. The task of a statute like the Code is to state basic principles under which business transactions can be carried out. This task does not require a scientific knowledge of each business fact-even if such knowledge were conceivably

in Article 9 of the matter of filing on security interests in consumer goods and certain farm equipment (supra, p. 355). I think that the treatment, which was an unhappy compromise between violently conflicting points of view, is nonsensical in its resort to filing as an arbitrary risk-shifting device which security hulders may use to protect themselves against purchasers who would otherwise take free of the security interest and who will never conceivably consult the filer. Others, who are as reasonable and intelligent men, felt that the solution, even though short of the ideal, had a good deal to be said in its favor. The point is a minor one because in practice most lenders on consumer goods do not file in any case except on automobiles, and the automobile situation is covered by the certificate of title laws which most states have already and which all will presumably have in a few years: Article 9 carefully meshes with such laws $(\$ 9-302(2))$. Furthermore the question of filing or non-filing on security interests in consumer goods is one of those on which legislatures may well decide to follow lomal policy. The question of local option was discussed at length at meetings of the Conference and Institute and generally agreed to; the final printed version of the Code is at fault in not making this clear in a Note, but the matter should be clarificd in the forthcoming Comments. (Mechanically all that is involved is the deletion of subsections (c) and (d) from Section 9-302(1). In states which choose to follow the present majority rule under conditional sales law and require filing as a condition of protection where consumer goods are concerned, the situation will be the same as under present law. To recapitulate: Beutel and I agree that in this respect Article 9 is ill-conceived. Other people disagree with us. The matter is not vitally important in any case. As it happens, an alternative solution is readily available, which, if adopted, would cut the ground from under the objections which Beutel and I share. I have drawn this discussiun out to sime length in order to make the foint that one flyspeck does not irretrievably ruin the picture. 
available, which it is not. "Science" performs miracles; we worship the controlled experiment of the laboratory man and think that salvation lies in applying his methods to everything we do. What we get, outside the laboratory, is an illusion of certainty. In the drafting of statutes a draftsman who is aware of the possibility of human error and walks cautiously is infinitely to be preferred to a pseudo-scientist who knows he has the truth. I am not an advocate of happy ignorance. What was needed-and achieved-in the drafting of the Code was a good working knowledge of the facts of business life. ${ }^{2}$

At this stage the Code could not be substantially improved by returning it to Institute and Conference, as Beutel suggests, and spending another few years drafting. There comes in everything a point of diminishing returns. Further drafting on this Code, if one accepts its basic structure, would be mostly tinkering-or else reopening policy questions which have already been endlessly debated and solved as well as anyone knew how.

It is fruitless to argue about the quality of the draftsmen; it is the quality of the drafting that counts. If the job is a good job, it would make no difference if the draftsmen had been respectable Hottentots.

Merely parrying Beutel's thrusts does not prove that the Code ought to be adopted. At most the parrying approach takes us no further than to say that the Code is no worse than the present state of the law and contains no obvious errors of fundamental importance. More than that is needed. Unless a convincing case can be made that the Code's adoption will improve the state of the law, it should not be adopted. That case has been made in part in the literature that has grown up around the Code during the past few years. Now that the final version is available, the case should be comprehensively restated. My task in this paper is, however, a more modest one.

A large part of the Code is restatement of the earlier Uniform Acts. This is necessarily true since we have had codifying statutes in the commercial law field for fifty years past. Once the need for recodification is admitted, the necessity of restating the matter contained in the earlier Acts attomatically follows. But Beutel has overstated the extent to which the Code is merely restatement by apparently assuming that the coverage of the various Articles of the Code is the same as the coverage of their analogttes among the earlier Acts. This is not true. The Sales Article of the Code consists in considerable part of material not touched by the Uniform Sales Act; the Investment Securities Article is far more comprehensive than the Stock Transfer Act; the Secured Transactions Article is a great deal more than a redoing of the Conditional Sales and Trust Receipts Acts. The restate-

2. My disclaimer of "scientific" methods of investigation is by no means an acceptance of Beutel's implied charges that little or no effort was made to discover the truc nature of things. On the contrary. No Article of the Code reached anything like final form without having undergone the intensive scrutiny of people-both lawycrs and operating men-who were intimately acquainted with the area of business practicc and law involved. 
ment in the Code obviously could not be avoided; it is frequently helpful in clearing up the many conflicts that have arisen in the judicial construction of the earlier Acts; ${ }^{3}$ there is also much more new matter in the Code than Beutel credits it with.

\section{TERAIINOLOGY}

Beutel is seriously concerned over the Code's terminology, its system of defined terms, which he characterizes as "an entirely new and strange vocabulary... highly technical and exotic language... a totally new set of terms...." Presumably Beutel would not expect this characterization to be taken literally; I appreciate it as invective. A casual run through the definitional sections of the Code will reveal that the great majority of the defined terms are hardy legal perennials. ${ }^{4}$ There are to start with the eighty or so terms found necessary in the earlier Uniform Acts. The coverage of the Code being notably greater than that of the earlier Acts, it is not surprising that additional terms had to be defined. The Sales Article, for example, codifies a wide area of basic contract law which the Uniform Sales Act did not touch: it was convenient to include definitions of such terms as "contract" and "agreement" which are not defined terms in the old Act but which, for all that, can hardly be stigmatized as rare or exotic blooms. Another class of defined terms came in because of distinctions taken in the Code which the earlier Acts did not make. The Sales Article differentiates at various points between the rights and duties of merchants and non-merchants: clearly the term "merchant" had to be defined. The Secured Transactions Article distinguishes among security transactions principally according to the type of collateral put up as security: it defines, among other types, "consumer goods," "equipment," "inventory" and "farm products." In one sense these are novel terms: they have not previously been statutory words of art. On the other hand it would be hard to imagine that either a businessman or a lawyer would find them "strange... technical and exotic."

Beutel has counted over one hundred and seventy defined terms in the Code, which is, he feels, too much. By contrast he points admiringly to the "highly successful commercial codes of Europe" which have "practically no definitions." I have myself no idea whether the European codes have been highly successful or not; assuming for argument that they have been, I would be

3. Consult Brannan's Negotlable Instrument Liw (Beutel's ed. 1948) fassin for the fifty or more cases of conflicting interpretation that have arisen under various sections of the NIL alone.

4. Section 1-201 collects definitions which apply generally through the Code as a whole. Each Article then contains in its intrcductory Part any additional definitions required for its own subject matter.

5. Both these definitions apsear in $\$ 1-201$.

6. $\$ 2-104$.

7. All these terms are defined in $\$ 9-109$. 
surprised to learn that it was because they contain no definitions. I do have some sympathy for Beutel's feeling that the Code is over-defined: I doubt, however, that the defect is a serious one. A little streamlining in this respect would have made the machine more attractive-without making it any easier to operate.

Beutel comes down to particulars in his charge that the Code contains a "series of multifarious and conflicting" definitions of certain basic terms.

A few of the items on Beutel's list of misused basic terms are trivial. The commercial world has long managed to maintain its equilibrium despite the fact that the word "account" is used in different contexts in the phrases "bank account" and "account receivable." Beutel seems to feel that dire consequences may be expected because the Bank Collection Article of the Code uses "account" in the "bank account" meaning, ${ }^{8}$ and the Secured Transactions Article uses it in the "account receivable" meaning. ${ }^{0} \mathrm{I}$ disagree. It occurs to me that the only other solution here would have been to invent some entirely new word: at that point Beutel would have criticized the draftsman for his use of "highly technical and exotic language."

Others are more serious and deserve examination.

Value. Beutel states that the Code contains four definitions of value,10 while in six of the seven earlier Uniform Acts the term received "almost identical definitions," with "slight variations" in the NIL. Two questions arise: were the definitions in the earlier Acts "almost identical?" Are the various senses in which "value" is used in the Code justifiable? Bettel does not tarry to argue the second question; on the first he is somewhat disingenutous. Six of the seven Acts, says Beutel, defined value as "any consideration sufficient to support a simple contract": this is correct except that the Trust Receipts Act (like Article 9 of the Code on Secured Transactions) found it necessary to define both "value" and "new value."11 The NIL, he says, contains the "same concept with slight variations," in contrast to Article 3 on Commercial Paper which radically differs from the others in that Section 3-304 excludes the extension of credit from the definition of value. Now, in fact, the NIL concept of value where due course holding is at issue differs from that in the other Uniform Acts in exactly the same way that the Article 3

8. $\$ 4-104$.

9. $\$ 9-106$. Beutel also objects to the use of "account debtor" (\$9-105) to describe the obligor on an account receivable, but, as I read him, not quite as violently as to the other two.

10. In fact there are five: see $\S \S 3-303 ; 4-208,4-209 ; 7-102 ; 8-303 ; 9-108 . \S 2-103(3)$ makes the definition in \$7-102 applicable to Article 2. The definitions in Articles 7, 8 and 9 are in substance identical with slight variations in language to fit the definition into the context of the particular Article. \$3-304 differs from the others in the manner pointed out in the text. $\S \$ 4-208$ and 209 are an exception in the bank collection situation from § 3-304.

11. UNiforM TRUST Receipts ACt $\$ 1$. 
concept differs from the rest of the Code. ${ }^{12}$ In this respect the Code merely reproduces a distinction which the earlier Acts had made and which most lawyers for esoteric reasons continue to feel desirable. Likewise the "value" "new value" distinction in Article 9 follows the Trust Receipts Act. All but one of the definitions of "value" in the Code are thus borrowed without change of substance from the earlier Acts. The only significant departure from established usage is in Article 4 (Bank Collections) which in substance gives a collecting bank a value position whenever it has given credit available for withdrawal as of right, whether or not the credit has actually been withdrawn. This is a change from the NIL value concept which has long been urged by most commentators-including Beutel..$^{13}$

In effect the Code says that value is any consideration sufficient to support a simple contract (including extension of credit) except that for the purpose of determining when a person other than a collecting bank is a holder in due course of a negotiable instrument, the extension of credit is not enough: the consideration must be executed. Is the exception necessary? There was considerable sentiment among members of the drafting staff in favor of abolishing the exception and thereby achieving a uniformity in this important concept which the earlier Acts had failed to do. This proposal met the massed opposition of the legal profession as represented in the Conference and Institute: lawyers apparently revere the NIL as dutiful sons revere their mother. Eventually, however, the drafting staff's proposals were accepted so far as bank credit was concerned, on the theory that bank credit is functionally different (as it is) from non-bank credit. Although the Code's "value" treatment is not unified as the drafting staff had hoped to malie it, it is an improvement over the earlier Acts without being more complex.

The Code also distinguishes in the field of secured transactions between

12. NIL $\$ 25$ defines value as "any consideration sufficient to support a simple contract" followed, as in the Acts, by language designed to make clear that antecedent debt is included. This is, however, seriously qualified by $\$ 54$ which reads: "Where the transferee receives notice of any infirmity in the instrument or defect in the title of the person negotiating the same before he has paid the full amount agreed to be paid therefor, he will be deemed a holder in due course only to the extent of the amount therctofore paid by him." The weight of the case law is clear that under $\$ 54$ the extension of credit, including bank credit, is not enough to give the transferee a holder in due course position. See BeUTEz's Braninan op. cit. sipra, note 3 , under $\$ 54$. Most commentators, including Beutel, have favored the opposite result. Ibid. Since the principal importance of the NIL's value concept lies in its application to the question whether a transferee is or is not a holder in due course, Beutel's statement, although it may be formally correct, is sadly misleading as to substance.

13. The language in the Code's "value" definitions is more precise and detailed than the language found in the earlier Acts, but there is no change in substance except possibly in the addition of the provision that taking delivery under pre-existing contracts constitutes the giving of value $(\$ \$ 7-102 ; 8-303 ; 9-10 \$)$. It is nut elear whether this constitutes "value" under the definitions in the earlier Acts. 
new and old value: ${ }^{14}$ that is between security interests taken for a present consideration and those taken for an antecedent debt. I cannot believe that Beutel means to suggest that security interests taken for antecedent debt be ranked in all cases on an equality with those taken for new value. If he does, I should be interested in hearing him explain why. If he does not, how would he suggest writing the statute without making the distinction?

This is an appropriate point at which to comment on a horrible example which appears at a later point in Beutel's paper but which, if I understand it correctly, relates to the Code treatment of value. Under the Code, says Beutel, when a draft and bill of lading are transferred together a bank transferee will take both draft and bill free of defenses but a merchant transferee will take only the bill of lading free of defenses and will remain stubject to defenses as a holder of the draft. Although Beutel does not make the point explicit, this result as to the merchant will follow only when the merchant has taken the draft on credit and has not paid for it; in view of the treatment of bank credit in the Code the bank, as he says, becomes a holder in duc course of the draft on the extension of checking credit available for withdrawal as of right. Beutel concludes that " $[u]$ nder the present uniform laws ... both the bank and the merchant would, under the words of the statutes, be holders for value and would take it [i.e. the draft] free from defenses or claims of former owners." 15 Here Beutel is in error. Under the present Acts both bank and merchant, provided there has been only an extension of credit and no payment, will indeed hold the bill of lading free of defenses; neither one, unless payment is made before notice, will be a holder in due course of the draft so as to hold it free of defenses. ${ }^{16}$ Assuming, as Beutel apparently does at

14. Strictly speaking, Article 9 contains no formal definition of "new value," although the term is used frequently: cf. $\$ 9-108(2)$. Elaborate definitions of the term, of varying degrees of incomprehensibility, appeared in earlier drafts. It was eventually decided to go ahead and use the term without definition in the "cheerful spirit" which Professor Corbin recommends to draftsmen faced with comparable problems: "The word 'title' is such a variable term, one that can create an illusion of certainty. With respect to its use, a reporter has several alternatives: (1) he can avoid its use altogether, with or without an explanation, substituting other terms in common use, stuch as ownership, property, property interests, rights; (2) he can continue to use it, accompanying it by a sort of strait-jacket in the form of a statutory definition, more or less verbose and perhaps containing several other variable terms: (3) he can use it in a cheerful spirit, without fear and without reproach-without fear that others will give it any specific meaning that will cause misunderstanding, and without the reproaches that are sure to follow if he tries to require his readers to accept it with a specific and limited meaning." Corbin, The Uniform Commercial Code-Sales; Should It Be Enacted? 59 Yale L. J. 821, 825 (1950).

15. See p. 349 , supra.

16. The NIL makes a confusing distinction between "holders for value" $(\$ 26)$ and "holders in due course" ( $\$ 52$ et seq.). Only holders in due course hold free of defenses and claims ( $\$ 57$ ). The result of $\S 54$ (see Note 12 , supra), is that although both bank and merchant become "holders for value" on the extension of credit, neither becomes at "holder in due course" until money is paid out. 
this point of his paper, that both his characters should be protected on both pieces of paper, the Code has at least solved the bank's situation correctly, while the merchant is left where he was under the NIL. Banks are, in fact, the only ones who regularly extend credit against mercantile drafts; it would be hard to imagine such a transaction involving a merchant. Beutel has not stated a problem of any practical importance. The possibility of a person in one transaction taking a bill of lading free of defenses and the accompanying draft subject to defenses has existed under the old Acts for nearly fifty years. I have never seen a case in which it has led to any difficulty. The reason for this is probably that the bill of lading is the vital document, which controls the goods which in turn are the underlying security; since the taker holds the bill free of defenses and equities, he can protect himself by resort to the goods in case of need and will not be unduly concerned at not being a holder in due course of the draft.

Good faith purchase for value. Beutel quarrels with the Code's retention of traditional terms to describe takers of various types of property, such as "good faith purchaser for value" of goods, "holder in due course" of a negotiable instrument, "assignee" of non-negotiable paper, and so on. This seems somewhat inconsistent with his earlier attack on the Code for not retaining traditional terms. The legal world has got along under this terminology for a hundred years or more; no trouble or confusion has arisen; it seemed pointless to make a revolution. It is true that theoretically one term could have been devised to cover all types of purchasers who on transfer acquire better title than their transferors had. I would not have enjoyed the task of persuading the members of the Conference and Institute that legal science required the Code to speak of holders in due course of chattels-but perhaps it could have been done. I do not remember that Beutel ever suggested at any meeting of Conference or Institute that this change in accepted terminology was necessary or desirable; he was wise in not malking the suggestion.

Notice. As to "notice" Beutel concludes that "the Negotiable Instruments Law is clear" where the Code is verbose and unclear. I will agree that the NIL contains only one short section dealing with "notice," and that the Code in Article 3 contains a long section ( $\$ 3-304$ ) dealing with notice as it affects purchasers of negotiable instruments and in addition a general definition of "notice" in Article 1 (\$1-201). However, the NIL's one short section did nothing to make the law clear. Rather the NIL left the question of what facts constitute notice sufficient to bar a taker from becoming a holder in due course largely to a case law development under the not too helpful language of Section 56. There has now been a fifty year accumulation of case law on the point, available to the 1950 draftsman. Section 3-307, therefore, drawing on the case law, codifies with some precision the effect of various factual situations as notice or not notice. In view of the pervasive influence of the concept of "notice" in the negotiable instruments field, the detailed 
treatment seems to be a good idea. Obviously it takes up a good deal more space than NIL Section 56.

Beutel also objects to some of the results which he believes will follow from the language of Section 3-304. On some of these, reasonable men may differ as to the desirable solution: some will prefer the Beutel view of policy, others will accept the view expressed in the Code. No one ever has drafted, or ever will draft, a statute which appears to everyone in the world to lead automatically to the one correct solution of every problem within its scope. I am surprised, however, to find Beutel apparently championing the NIL treatment of the so-called restrictive indorsement or indorsement in trust. I had thought that everyone in the world had agreed that at this point the NIL broke down completely. ${ }^{17}$ The Code, following the Uniform Fiduciaries Act, ${ }^{18}$ does not put takers of instruments from fiduciaries on notice of a breach of trust merely by reason of the fiduciary's holding the instrument under a trust indorsement. This was not the original common-law position, nor the NIL position. It does correspond with much modern writing on the subject, ${ }^{10}$ and is no doubt the law today in the states which have adopted the Fiduciaries Act, which appears to repeal or amend the NIL on this point.

Although Beutel dislikes the treatment of trust indorsements, he finds the Code inconsistent in not treating conditional indorsements the same way. He is right about the inconsistency. "On the other hand there are few modern cases involving conditional indorsements and the leading one dates back to the Napoleonic wars."20 It might be thought a matter of relative,indifference what the draftsman did about it.

While it is clear that Beutel dislikes Section 3-304, the reason why is not always easy to unriddle. At one point Beutel seems to object to the fact that the terms "claims" and "defenses" are not given statutory definitionsany more than were the analagous terms "defects of title" and "infirmities" in the NIL. Then, as a continuation, he states a case (a check with the payee's name left blank) which comes out the same way under the Code that it did under the NIL (one who takes the instrument in that condition will not be a holder in due course). Apparently Beutel does not object to the result. What he seems to be saying is that Section 3-304 is wrong in treating the blank payee line situation as a defense; what it really is, he

17. Basse, Restrictive Indorsements, 52 Yale L. J. 890 (1943); Chafee, Restrictiv' Indorsements, 58 HaRv. L. Rev. 1182 (1945). See cases and comments collccted in BEUTEL's BRANNAN op. cit., supra, note 3 under $\$ \$ 36$ and 37.

18. Uniform Fiductaries Act $\S 4$.

19. See 2 Scotr, LAw of Trusts (1939) $\$ 297.6$

20. Robertson v. Kensington, 4 Taunt. 30 (1811). See Commissioners' Note to NIL \$39; Beuter's BranNan op. cit., supra, note 3 under $\$ 39$. The indorsement involved read: "Pay the within sum to Messrs. Clerk \& Ross, or order, upon my name appearing in the Gazette as ensign in any regiment of the line between the 1st and 64th, if within two months from this date." 
suggests, is an "infirmity" or an "irregularity." That is: although it operates as a defense, it should not be called one but should be called something else which means the same thing.

\section{CONFLICT OF LAWS}

Beutel and others have been saddened by Section 1-105 which states rules to determine the applicability of the Code. Under that Section, if State A has enacted the Code, and litigation on a subject matter covered by the Code arises in State A, the State A courts are directed to apply the Code (that is, the local law) in a great many situations where conventional conflicts rules would require the application of the law of some other jurisdiction. This has depressed most experts on the law of the conflict of laws.

Beutel states the case of a transcontinental shipment of goods passing through fifteen states en route from seller to buyer and remarks that the parties might find themselves bound by the law of any one of those states "where either party might choose to sue." I take it the joker is in the quoted language: after all $A$ does not sue $B$ in North Dakota unless $B$ is in that state or has property there. A does not sue B in North Dakota merely because a freight car loaded with B's goods once passed through North Dakota. There are, it is true, multi-state enterprises with property in several states. If $B$ were such an enterprise and had a warehouse in North Dakota, A could, under Section 1-105, sue B in North Dakota and get the benefit of North Dakota law (the Code) although the only contact the A-B transaction had with that state was the passage of the freight car across the Daliota plains. That is, he could unless the parties in their contract had stipulated for, say, the law of New York or California where, we shall assume, the parties were in business. ${ }^{21}$ Multi-state enterprises have, or ought to have, lawyers astute enough to draft a simple contract. Local businesses need not bother. Although I claim no expertness in conflicts, I do believe that Beutel and his brother wizards are conjuring up ghosts in their fifteen state transactions with the frightening possibility of suit anywhere along the line with the forum applying its own law.

Beutel closes his conflicts discussion by imagining some court wrestling with provisions of the Code which command it to apply the laws of half a dozen different States to various facets of one transaction. Here Beutel has inexplicably fallen into the error which, in my own ignorance of conflicts, I tend to share unless I make a great effort beforehand. The answer is that

21. "Whenever a contract, instrument, document, security or transaction bears a reasonable relationship to one or more states or nations in addition to this state the parties may agree that the law of any such other state or nation shall govern their rights and duties. In the absence of an agreement which meets the requirements of this subsection, this Act governs." $\$ 1-105(6)$. 
the Code's conflict rules are merely directions to the courts of State A to apply its own law (in the absence of a choice of law clause in the contract) in certain cases. The Code's rules do not direct the State A court to apply State B's law in the event that State B also has a contact with the transaction. If State $A$ has no contact which under the Code authorizes the State A court to apply its own law, then the selection of governing law by the court is left to conventional conflicts rules which the Code does not attempt to codify.

\section{Article 4-Bank Deposits and Collections}

Beutel characterizes Article 4 as "a piece of vicious class legislation" and "a deliberate sell-out ... to the bank lobby." He criticizes a number of provisions of the Article in detail and concludes: "The existence of Article 4 alone is enough to condemn in its entirety the adoption of this 'Code'."

While I do not agree with many of the details of Beutel's criticism of Article 4, I do not care to urge enactment of the present text of the Article. I shall therefore forego discussion of the provisions of the Article which Beutel draws in question, leaving that task to someone who can undertake it with a better heart. ${ }^{22}$

As Beutel says, the version of Article 4 adopted by the joint meeting of Institute and Conference in September, 1951, was proposed by a group of bank counsel during the preceding summer. I do not suggest that their activity was improper: it was entirely reasonable for them to make a final effort at finding an acceptable solution. It is true that no member of the drafting staff for the Code participated in their work and that the resulting draft was presented to the joint meeting with almost no opportunity for preliminary studly by anyone outside the banking group. A few amendments, proposed by the drafting staff on behalf of the Commercial Acts Section of the Conference, were incorporated in the final text. ${ }^{23}$

22. Specifically, I disagree with what Beutel has to say about the following Sections: $4-201 ; 4-203 ; 4-205 ; 4-208 ; 4-209 ; 3-603 ; 4-406 ; 4-407$. While I do not mean to say that there is nothing in those Sections to which I would object, I feel that the particular points which Beutel has criticized are reasonable and proper. In most cases the provisions which Beutel now cites as examples of banker's itch were carried forward substantially without change from the early drafts prepared by Mr. Leary, whom Beutel apparently looks on as an honest man fallen among thieves. I hasten to add that I entircly share Beutel's high estimate of Mr. Leary's probity and ability. Mr. Leary withdrew from active participation in the drafting of Article 4 during the summer of 1950 because of the increasing demands of his practice. On the extent to which the final version of Article 4 differed from the earlier drafts, see note 23 infra.

23. References here and in Beutel's article to the "Summer, 1951" draft should not be read to mean that that draft, which, with the amendments referred to, was the one adopted as the final version, was in all respects different from the earlier drafts of the Article. The May, 1951, joint meeting of Conference and Institute had voted to delete the Article from the Code: this action was taken because on three or four issues, thought 
The feature of Article 4 as it appears in the final version of the Code which is enough to make the entire Article objectionable is the freedom of contract section, $\$ 4-103$. This Section as drafted provides that banks may by general or special agreement contract out of any of the rules laid down in the balance of the Article, provided only that a bank may not disclaim responsibility for the exercise of good faith and ordinary care. The proviso is, however, subject to a double-barrelled exception: 1) banks may agree on what constitutes ordinary care; 2) even in the absence of agreement, any action taken by a bank which is consistent with "a banling usage" is ordinary care. It should be noted further that the "general agreements" by which banks may amend the Article as they see fit, or agree on what ordinary care is, are agreements between banks to which the customer who deposits an item for collection is not a party but by which he will be bound.24

This is carrying a good joke too far. The only bright spots are: 1) that a court, construing Section $4-103$ according to its fair meaning, might be disposed to hold the Article unconstitutional as an improper delegation of legis-

to be crucial, it had proved impossible after years of negatiation to reach a solution which was acceptable both to the sponsoring organizations and to the group of banl: counsel, including representatives of the Federal Reserve system, which had participated in the discussions. Brome, Bank Deposits and Collections, 16 Law \& Co: Tesr. Pron. 308 (1951), written from the banker's point of view, indicates the major areas of disagreement. Of these the most important was the question of "freedum of contract," $\$ 4-103$, discussed in the following paragraph of the text. The "Summer, 1951" draft resolved these issues in the way that the banking representatives had argued for. Otherwise the "Summer, 1951" draft mostly reproduced the "Spring, 1951" drait, malzing minor changes, some of them excellent, in an attempt to simplify the language. What had been Part 3 of the Article in the "Spring, 1951" draft (Cillectiun wi Lesumentary" Drafts) was deleted from the final version. Miost of the material thus deleted frum Article 4 appears in the November, 1951 text of the Code as Sections 3-701 through 3-704.

24. "'General Agreement' means Federal Reserve regulations or operating letters, clearing house rules, or the like" (\$4-104(1)(g) ). "'Special Agreement' means an agreement between affected parties with respect to particular items or particular situntions." (\$4-104(1)(1).). These definitions were among the last minute amendments referred to in the text supra and were designed to limit the scope of \$4-103 as originally presented in a mimeographed draft dated August, 1951. There would be nothing objectionable in delegating to the Federal Reserve Board through its regulations power to amend the basic statute so far as operating methods are concerned. The "general agreement" definition also includes "Federal Reserve... operating letters": these letters, sometimes called "circulars," are issued by the local Reserve Banks and not by the Board and are meant to cover only details of operation. (See Regulation $J$ of the Federal Reserve Board.) "Clearing house rules" are rules adopted by the banks which are members of a clearing house to regulate its operation. But how far do the little words "or the like" take us? An agreement among banks which belong to the State Banlier's Associstion? A collection agreement between any group of banks, two or more? So far as I am presentiy advised, the Comment to the definition of "general agreement" will do nothing to clarify the situation. 
lative power to private interests $; 25$ 2) that Section $4-103$ contains more than one loophole in the drafting on which a court might well seize to limit the scope of "variation by agreement" which the Section was designed to permit.

The principal defense of Section 4-103 runs along these lines: Bank collections is a highly technical field; the operation, because of the enormous number of items handled by banks, must be routinized; as conditions change, new operating procedures become necessary-it would therefore be unwise to freeze any particular procedure by statute; bankers are the only people with a sufficient understanding of the technical processes to establish reasonable rules; it is absurd, fanciful and professorial to imagine that banks would ever take undue advantage of their customers. Parts of this argument are entirely sound. I have not been convinced that it can ever be sound legislative policy to write a blank check to the order of any private interest group in the community.

Let us not overstate the case. I do not believe that it is time to man the barricades. Our way of life will not be in jeopardy even if Article 4 is enacted. Luncheon at the Bankers' Club is not given over to devising ways and means of hoisting the poor customer each day a little higher on his own petard. I do not ascribe to the draftsmen of the final version of Article 4 motives which are in any way improper or malevolent.

A cheap, speedy and efficient collection system is in the private interest of banks as much as it is in the public interest of customers of banks. We may anticipate that in general and in good times banks would use the powers conferred on them under $\$ 4-103$ in a good faith effort to improve the collection system. But there are bad times as well as good times; there may even be bad banks as well as good banks. Section 4-103 goes far beyond what is wise or permissible in allowing banks to rewrite the law their way when-

25. The spectre of unconstitutionality which $I$ am raising here is not the same spectre which Beutel flourishes (supra p. 000). Indeed Beutel's is no spectre but at thing of fiesh and blood. The Bank Collection Code was held unconstitutional as to nationtal banks in Jennings v. United States Fidelity \& Guaranty Co., 294 U.S. 216 (1935) and in two states (People v. Union Bank \& Trust Co., 362 I1l. 164, 199 N.E. 272 (1935); in re Riverton State Bank, 48 Wyo. 372, 49 P. 2d. (1935) as to state banks as wcll. The Supreme Court decision was based on a construction of $\$ 194$ of the National Bank Act (12 U.S.C. $\$ 194$ (1946) ) : the Court held that the sections of the Bank Collection Code giving the owner of an item a preference or trust in the assets of an insolvent collecting bank were repugnant to $\S 194$. The state decisions were based on the theory that the legislature would not have intended the Act to apply to state banks if it could not apply to national banks. Since Article 4 of the Commercial Code reproduces in substance the preference provisions of the Bank Collection Code, it is of course unconstitutional, at least as to national banks, as the law now stands. It has been entirely clear that for the preference provisions to stand, it will be necessary to amend $\S 194$ of the Nationtal Bank Act; my understanding is that the Federal Reserve System would be willing to recommend such an amendment to the Congress. The preference provisions are an attempt to protect the depositors of items, in collection but not collected, against the insolvency of collecting and payor banks. The unconstitutionality to which Beutel refers arises, that is, from the fact that in this respect Article 4 is pro-depositor rather than pro-bank. 
ever things get tough: say, a general extension of all time limits because of difficulty in finding trained personnel during a war period. 0

I agree, then, that Article 4 as it now reads should not be enacted, as part of the Code or in any other guise. However, if the present text of Article 4, and particularly of Section 4-103, were revised so as to place appropriate limitations on contracting out of the statute, there would be no insuperable objections to the balance of the Article. I have been advised that the group of bank counsel which was instrumental in preparing the Summer, 1951 draft is presently considering recommending such revisions to the Institute and Conference.

It does not follow that if Article 4 is not amended the entire Code has to be thrown out.

The deletion of Article 4 from the Code is fortunately a simple matter which raises no technical difficulties. The Article happens not to be closely integrated with any of the other Articles: Article 3 contains perhaps a halfdozen cross references to Article 4 which should for the sake of elegance be stricken if Article 4 is deleted; if they were not stricken I cannot see that any harm would be done. I do not believe that there is any reference to Article 4 in any of the other Articles. No legislature, contemplating the deletion of Article 4, need fear that any untoward results would flow, so far as the rest of the Code is concerned, from the deletion.

Beutel does not suggest that the baleful influences which presided at the final delivery of Article 4 operated over the rest of the Code. Nor did they. The banks were principally concerned, as they had every right to be, with Articles 4 on Bank Collections and 5 on Letters of Credit. On the Letters of Credit Article a solution satisfactory to all parties was eventually arrived at, of which even Beutel seems to approve. On no other part of the Code did there ever develop a situation comparable to the Article 4 imbroglio or one which led to the making of such undue concessions to special interest groups. The Code is not of course a reform statute; it is not designed to bring the millennium; it comes into the world neither a little Liberal nor yet a little

26. Delays beyond prescribed limits are authorized by $\$ 4-10 \$(2)$ "if caused by" interruption of communication facilities, suspension of payments by another bank, war, emergency conditions or other circumstances beyond the control of the bank provided it exercises such diligence as the circumstances require" This is a proper and reasonable provision. Under it, in the case of any delay sought to be excused, factual proof would be required to show that the cause of the delay was one of the listed reasons. Under $\$ 4-103$, however, banks could by general or special agreement extend time limits generally and a court could not, if the statute means what it says, inquire into the reasons for the extension. This gives a great deal too much discretion to the banls in deciding hard questions their way without even the possibility of judicial review. Under earlier drafts of the Article, $\$ 4103$ provided that time limits prescribed by the Article could not be varied by agreement; $\$ 410 \$$ provided a necessary eseape clause where time limits could not be met because of circumstances beyond the bank's control. 
Conservative. It is an honest effort to state basic rules of commercial law which reflect, more accurately and flexibly than do the present rules, going methods of operation.

\section{CoNCLUSION}

With the best will in the world Beutel has not-except for Article 4turned up anything damaging. Where he has caught the Code in error or inconsistency, the point at issue proves to be on analysis a theoretical blemish which will have few, if any, undesirable consequences in practice and, frequently enough, is one where the Code has continued existing law unchanged. ${ }^{27}$ There are many points where Beutel is in disagreement with substantive provisions of the Code and on some of them $I$ feel as he does: I think he has raised no point of policy which was not, during the drafting of the Code, elaborately canvassed at staff meetings, at advisers' meetings, at conferences with members and representatives of various industries, before the Council of the Institute, the Commercial Acts Section of the Conference and the general meetings of both organizations. No statute ever drafted has over so long a period in advance of its promulgation received such intensive study from so large a part of the legal profession and affected commercial interests. Drafts of the Code have been publicly available and widely circulated for several years past: no basic policy decision on a controversial issue has escaped debate. An examination of successive drafts of the Code will reveal the truly extraordinary number of changes that were made in response to criticism and in an effort to simplify and unify: pride of authorship was not involved. While Beutel may question the wisdom

27. Occasionally Beutel writes as if he had not read the text which he is criticizing. At this point I will mildly complain of his statement that the definition of "consumer goods" (\$9-109) "does not make it clear whether an inventory of the same articles in a merchant's shop fall within the technical definition of consumer goods or not." The definition reads as follows: "Goods are 'consumer goods' if they are used or bought for use primarily for personal, family or household purposes." In view of the "used or bought for use" language I find it impossible to understand Beutel's statement. Similarly Beutel's discussion of Section 9-206 (see pp. 355-6 supra) must be based on a misreading of the statutory text, which he cites but which does not support his comments. Beutel's suggestion that an assignee would have different rights depending on whether he sted to enforce the security agreement under Article 9 or on an accompanying negotiable instrument under Article 3 is negatived by $\S 3-103$ which makes the Article 9 provision paramount. (I agree that Section 9-309 which he also cites in this connection is imperfectly drafted, but, on the principle that the more specific provision prevails over the more general, I cannot see that any court would have the least difficulty with the question.) Finally, Beutel's "simple" solution of the' matter covered by Section 9-206(2) is defective since it deals only with "security agreements attached to negotiable instruments" whereas the subsection is drafted to cover not only that situation but also the more important case of the agreement not to assert defenses against an assignee which is contained in the security agreement itself without the use of an accompanying instrument. 
of some of the decisions made, it cannot be pretended that these decisions were made improvidently or without patient inquiry.

The most attractive argument against the Code is its sheer bulk. It's too big; it's too long; it weighs too much. Beutel makes an effective debater's point with Section 9-312, for example, which deals with priorities among conflicting security interests which attach to the same collateral. Look, he seems to say: We all know this stuff is simple as $A B C$, shouldn't take more than a few lines at most, but some mad genius actually dreamed up eight subsections and the damn thing runs two full pages. End of argument. I suggest that this is argument on approximately the same intellectual level as the demands for economy in the Federal government without specification of the places at which economy is feasible. I am wholeheartedly in favor of federal economy; I would be wholeheartedly in favor of shortening Section 9-312 if Beutel would tell us where to start cutting. The breaking down of a comlicated question into manageable components is a lengthy process: oversimplification and clarity are not the same things, and the doubtful expedient of pretending that hard questions don't exist may well be the longest way home. A happy stroke of drafting would have simplified the occasional section which came out in over-wordy and difficult language. But the Code as a whole is long because it covers a great deal of territory; it repeals a great deal more than its own weight in superseded statute and case law. Although lawyers will have to familiarize themselves with the Code when it is enacted, which will be a chore, they will on the other hand be relieved of the much greater burden of running down answers to questions through a maze of unrelated statutes, drafted fifty years ago and often reflecting business practice of a hundred years ago, not to mention the labyrinth of case law which has grown up around them.

The job of recodification was a necessary one; this Code is a good piece of work and will do much to improve the state of the law over the next fifty years. I would be for it even with Article 4 included, although Article 4 can and should be deleted.

Beutel has not made a persuasive case to the contrary. 